\title{
3 \\ CONCEPTUALISING AND MEASURING ECONOMIC RESILIENCE
}

Lino Briguglio, Gordon Cordina, Nadia Farrugia and Stephanie Vella

Many small states ${ }^{1}$ manage to generate a relatively high GDP per capita compared to other developing countries ${ }^{2}$ in spite of their high exposure to external economic shocks. This would seem to suggest that there are factors which may offset the disadvantages associated with such vulnerability. This phenomenon is termed by Briguglio (2003) as the 'Singapore Paradox', referring to the fact that Singapore is highly exposed to external shocks, and yet this island state has managed to register high rates of economic growth and high GNP per capita. This reality can be explained in terms of Singapore's ability to build its economic resilience.

Economic vulnerability is well-documented in the literature from both the conceptual and empirical viewpoints (see for example Briguglio 1995, 2003; Crowards 2000; Atkins et al. 2000). Most studies on economic vulnerability provide empirical evidence that small states, particularly island ones, tend to be more economically vulnerable than other groups of countries, due mostly to a high degree of economic openness and a high degree of export concentration. These lead to exposure to exogenous shocks, which could constitute a disadvantage to economic development by magnifying the element of risk in growth processes. Cordina (2004a, 2004b) shows that increased risk can adversely affect economic growth as the negative effects of downside shocks are larger than those of countervailing effects of positive shocks. The high degree of fluctuation in GDP and in export earnings registered by many small states is considered one of the manifestations of such exposure (see Atkins et al. 2000). 


\section{THE 'SINGAPORE' PARADOX}

As already explained, the 'Singapore Paradox' refers to the seeming contradiction that a country can be highly vulnerable and yet attain high levels of GDP per capita. Briguglio $(2003,2004)$ explains this in terms of the juxtaposition of economic vulnerability and economic resilience and proposed a methodological approach in this regard. In this approach, economic vulnerability was confined to inherent permanent or quasi-permanent features, while economic resilience was associated with man-made measures, which enable a country to withstand or bounce back from the negative effects of external shocks. Briguglio refers to this type of resilience as 'nurtured'. Cordina (2004a, 2004b) presents a conceptual application of this approach by showing that saving and capital formation in an economy, in response to a situation of vulnerability, can be important sources of resilience.

On the basis of this distinction, Briguglio (2004) identifies four possible scenarios into which countries may be placed according to their vulnerability and resilience characteristics—-described as 'best-case', 'worst-case', 'self-made', and 'prodigal son'.

Countries classified as 'self-made' are those with a high degree of inherent economic vulnerability, but which adopt appropriate policies enabling them to cope with or withstand their vulnerability. They take steps to mitigate their inherent vulnerability by building their economic resilience.

Countries falling within the 'prodigal son' category are those with a relatively low degree of inherent economic vulnerability, but which adopt policies that expose them to the adverse effects of exogenous shocks. The analogy with the prodigal son is that these countries, though 'born in a good family', squander their riches.

The 'best-case' scenario applies to countries that are not inherently highly vulnerable and which at the same time adopt resilience-building policies. On the other hand, the 'worst-case' scenario refers to countries that are inherently highly vulnerable and yet adopt policies that exacerbate that vulnerability.

These four scenarios are depicted in Figure 3.1, where the axes measure inherent economic vulnerability and nurtured resilience, respectively. In this scheme, the best situation in economic terms falls in quadrant II. The vulnerable small island states that have adopted resilience-building policies would fall in quadrant I. 
Figure 3.1 The four scenarios

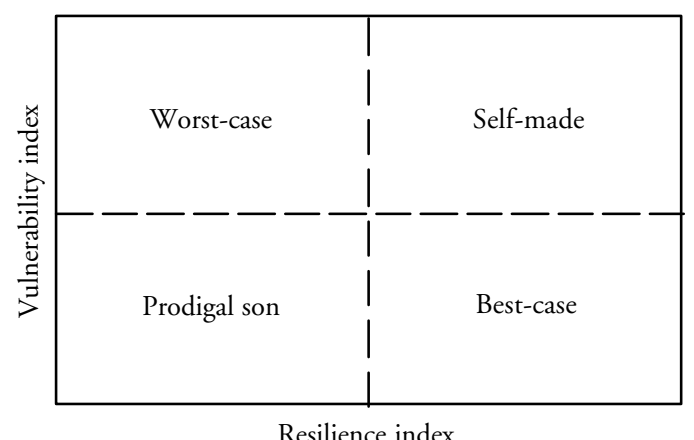

The method of defining vulnerability in terms of inherent features and resilience in terms of policy-induced changes has a number of advantages. First, the vulnerability index would refer to permanent (or quasi-permanent) features over which a country can practically exercise no control and therefore cannot be attributed to bad governance. As such, the index should not differ much over time. In other words, countries scoring highly on the index cannot be accused of inflicting vulnerability on themselves through misguided policy approaches.

Second, the resilience index would refer to what a country can do to mitigate or exacerbate its inherent vulnerability. Scores on this index would, therefore, reflect the appropriateness of policy measures.

Third, the combination of the two indices would indicate the overall risk of being harmed by external shocks due to inherent vulnerability features counterbalanced to different extents by policy measures.

Given these conditions it is highly unlikely that countries will be able to move vertically on this schema, but they will be able to move horizontally. It would thus be possible for countries to switch between the 'worst case' and the 'self-made' classifications, or the 'prodigal son' and the 'best case' classifications by changing their economic policies.

By distinguishing between inherent economic vulnerability and nurtured economic resilience, it is possible to create a methodological framework for assessing the risk of being affected by external shocks (Figure 3.2).

Figure 3.2 shows that risk has two elements, the first is associated with the inherent conditions of the country that is exposed and the second associated with conditions developed to absorb, cope with, or bounce back from, external shocks. The risk of being adversely affected by the shock is therefore the 
Figure 3.2 Risks associated with being adversely affected by external shocks

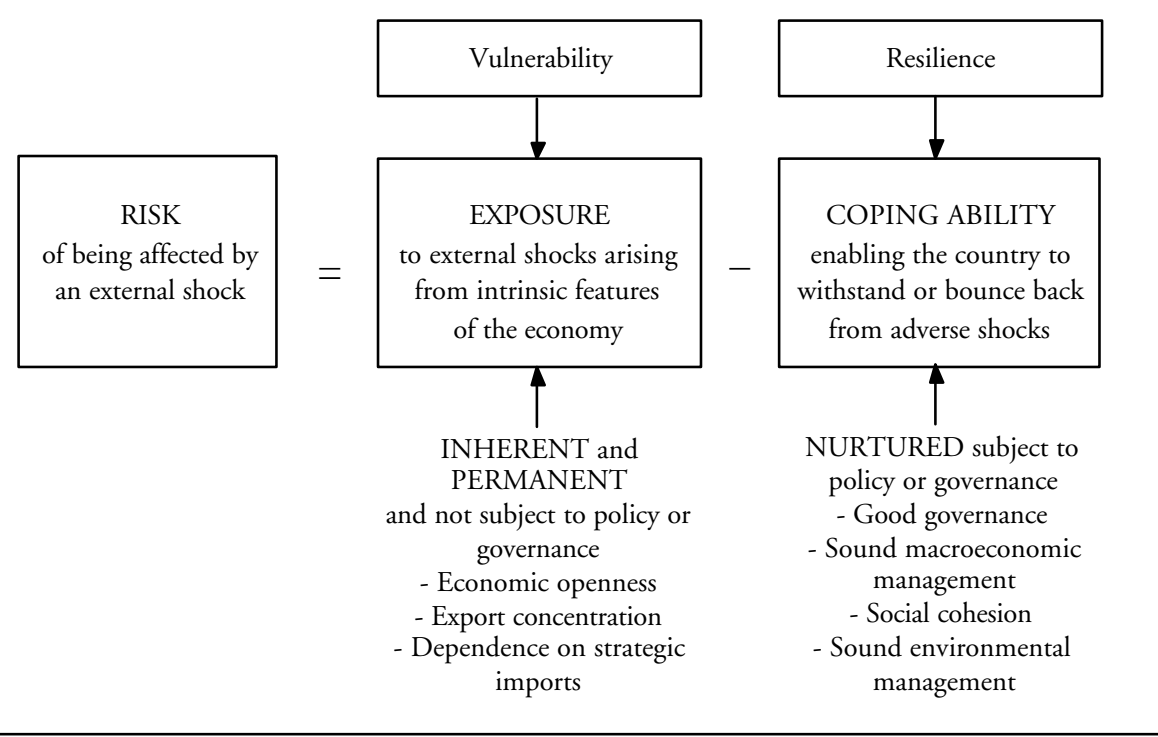

combination of the two elements. The negative sign in front of the resilience element indicates that the risk is reduced as resilience builds up.

\section{ECONOMIC VULNERABILITY}

Recent work on the economic vulnerability index (see Briguglio 1995, 1997; Briguglio and Galea 2003; Farrugia 2004) is based on the premise that a country's susceptibility to exogenous shocks stems from a number of inherent economic features, including high degrees of economic openness, export concentration and dependence on strategic imports.

\section{Economic openness}

Economic openness can be measured as the ratio of international trade to GDP. A high degree of economic openness renders a country susceptible to external economic conditions over which it has no direct control. Economic openness is, to an extent, an inherent feature of an economy, conditioned mainly by a country's ability to produce efficiently the range of goods and services required to satisfy its aggregate demand. If a country's productive base is limited to a narrow range of products, it has to rely on imports to service a substantial part of its needs and on exports to finance its import bill. 
It may be argued that openness to international trade is influenced by policy. Practical experience has, however, shown that trade policies tend to influence the composition of a country's external trade flows, rather than their size. It can be further argued that openness to international trade could be a source of strength, in that it may indicate that a country is successfully participating in international markets. This argument, however, does not detract from the fact that, by participating more actively in international trade, a country exposes itself to a larger degree of shocks over which it has relatively little control. ${ }^{3}$

\section{Export concentration}

Dependence on a narrow range of exports gives rise to risks associated with lack of diversification, and therefore exacerbates vulnerability associated with economic openness. Again, this condition is to a large extent the result of inherent features in the production base of an economy. Export concentration can be measured by the UNCTAD index of merchandise trade (UNCTAD 2003:section 8), and Briguglio (1997) and Briguglio and Galea (2003) have devised an alternative index which also takes services into account.

\section{Dependence on strategic imports}

Another facet of the exposure argument relates to the dependence on strategic imports, which would expose an economy to shocks with regard to the availability and costs of such imports. This variable can be measured as the ratio of the imports of energy, food or industrial supplies to GDP. Again, this condition is inherent in that it depends on country size, resource endowments and possibilities for import-substitution.

All vulnerability indices utilising these variables come to the conclusion that there is a tendency for small states to be more economically vulnerable than other groups of countries.

\section{ECONOMIC RESILIENCE}

Economic resilience can be defined in many ways, but here the term is used to refer to the ability to recover from, or adjust to, the negative impacts of external economic shocks.

\section{Usefulness of considering resilience building}

The issue of resilience building is important for small states in view of the fact that such states tend to be inherently economically vulnerable, as already 
explained. In addition, the discussion on resilience sheds light as to why a number of vulnerable small states have managed to do well economically, in spite of (and not because of) being highly exposed to external shocks. Consideration of resilience building also conveys the message that vulnerable states should not be complacent in the face of their economic vulnerability, but could, and should, adopt policy measures that improve their ability to cope with external shocks.

\section{The meaning of economic resilience}

Most dictionaries define resilience in terms of the ability to recover quickly from the effect of an adverse incident. This definition originates from the Latin resilire 'to leap back'. In economic literature, the term has been used in at least three senses relating to the ability to recover quickly from a shock, withstand the effect of a shock, and avoid the shock altogether. ${ }^{4}$

Ability of an economy to recover quickly. This is associated with the flexibility of an economy, enabling it to bounce back after being adversely affected by a shock. This ability will be severely limited if, for example, there is a chronic tendency for large fiscal deficits or high rates of unemployment. On the other hand, this ability will be enhanced when the economy possesses discretionary policy tools that it can utilise to counteract the effects of negative shocks, such as a strong fiscal position allowing discretionary expenditure or tax cuts to counter the shocks. This type of resilience is therefore associated with 'shockcounteraction'.

Ability to withstand shocks. This suggests that the adverse effect of a shock can be absorbed or neutered, so that the end effect is zero or negligible. This type of resilience occurs when the economy has in place mechanisms to react endogenously to negative shocks to reduce their effects, which we can refer to as 'shock-absorption'. For example, the existence of a flexible, multi-skilled labour force could act as an instrument of shock absorption, as negative external demand shocks affecting a particular sector of economic activity can be relatively easily met by shifting resources to another sector enjoying stronger demand.

Ability of an economy to avoid shocks. In this chapter, this type of resilience is considered to be inherent, and can be considered the obverse of economic vulnerability. 


\section{THE CONSTRUCTION OF A RESILIENCE INDEX}

\section{Underlying difficulties}

In this section, we present the results of an attempt to construct a composite index of economic resilience. Some words of caution are warranted at this stage. The choice of variables as components of the index is somewhat subjective. Care was taken, however, to base the choice on a set of desirable criteria related to: appropriate coverage, simplicity and ease of comprehension, affordability, suitability for international comparisons and transparency. A more detailed consideration of these criteria is given in Briguglio (2003).

In addition, the summing of the components of the index also involves subjective choices, principally in selecting a weighting procedure. There is considerable debate in the literature on composite indices on this issue. Again, these questions are discussed in Briguglio (2003) and are not elaborated upon here.

The compilation of the index encountered a number of problems with regard to data collection, the most important of which were associated with lack or shortage of data and non-homogenous definitions across countries. Briguglio (2003) considers these problems, referring to the fact that data problems occur particularly in the case of small states.

\section{Components of the resilience index}

It is hypothesised that elements of 'shock-absorbing' and 'shock-counteracting' resilience in an economy can be found in the following areas

- macroeconomic stability

- microeconomic market efficiency

- good governance

- social development.

All of these areas feature variables which are highly influenced by economic policy and which can serve for an economy to build its economic resilience to meet the consequences of adverse shocks.

Macroeconomic stability. Macroeconomic stability relates to the interaction between an economy's aggregate demand and aggregate supply. If aggregate expenditure in an economy moves in equilibrium with aggregate supply, the economy is characterised by internal balance, manifested in a sustainable fiscal position, low price inflation and an unemployment rate close to the natural rate, as well as by external balance, indicated by the international current account position or by the level of external debt. All these variables are highly 
influenced by economic policy and can act as good indicators of an economy's resilience in facing adverse shocks.

The macroeconomic stability aspect of the resilience index is thus constructed on the basis of three variables, namely

- the fiscal deficit to GDP ratio

- the sum of the unemployment and inflation rates

- the external debt to GDP ratio.

These variables are available for a set of 102 countries spread over a spectrum of stages of development, size and geographical characteristics. The relative data and country ranking results are presented in Table A3.1.

Fiscal deficit. The government budget position is suitable for inclusion in the resilience index because it is the result of fiscal policy, which is one of the main tools available to government, and indicates resilience of a shock-counteracting nature. This is because a healthy fiscal position allows adjustments to taxation and expenditure policies in the face of adverse shocks. The fiscal deficit, standardised as a ratio to GDP, is thus included in the resilience index proposed in this paper.

Inflation and unemployment. Price inflation and unemployment are also considered suitable indicators of resilience and at the same time they potentially provide information additional to that contained in the fiscal deficit variable. This is because price inflation and unemployment are strongly influenced by other types of economic policy, including monetary and supply-side policies. They are associated with resilience, because if an economy already has high levels of unemployment and inflation, it is likely that adverse shocks will impose significant costs. If, on the other hand, the economy has low levels of inflation and unemployment, it can withstand adverse shocks to these variables without excessive welfare costs. In this sense, therefore, unemployment and inflation indicate resilience of a shock-absorbing nature. The sum of these two variables, also known as the Economic Discomfort Index (or Economic Misery Index), is thus included in the resilience index proposed here.

External debt. The adequacy of external policy may be gauged through the inclusion of the external debt to GDP ratio. This is considered a good measure of resilience because a country with a high level of external debt may find it more difficult to mobilise resources to offset the effects of external shocks. Thus, this variable would indicate resilience of a shock-counteracting nature. ${ }^{5}$ 
It may be surprising to observe that the United States is not among the first 10 placed in the macroeconomic stability index, although it ranks at a relatively high place in $12^{\text {th }}$ position. A number of small states, on the other hand, notably Hong Kong and Singapore, rank high on the index. In this regard, it should be borne in mind that this index is not a measure of economic development but instead represents the ability of the macroeconomy to absorb or counteract adverse economic shocks.

Microeconomic market efficiency. The science of economics views markets, and their efficient operation through the price mechanism, as the best way to allocate resources in the economy. If markets adjust rapidly to achieve equilibrium, then the effects of shocks can be easily absorbed in the economy and the relative adjustments be readily affected. If, on the other hand, market disequilibria tend to persist, especially in the face of adverse shocks, then resources will not be efficiently allocated in the economy, resulting in welfare costs, manifested, for instance, in outflows of capital, unemployed resources and waste or shortages in the goods markets.

As an example, consider the case of financial markets. If, in the face of an adverse shock, markets respond efficiently by increasing interest rates and decreasing asset prices, capital can be retained in the economy such that the adverse shocks are reflected in price variables rather than in the volume of physical investment, which would have an important influence on economic activity. If, on the other hand, prices in the financial markets fail to adjust properly, then it is more likely that capital will leave the economy in the face of an adverse shock, thereby affecting economic activity and employment. Similar considerations may be made for the way in which the labour and product markets equilibrate in the economy. These issues have important implications for resilience of the shock-absorbing type.

Not many indicators of market efficiency are available for a range of countries sufficiently wide for the purposes of this study. Following a search for suitable indicators, it was decided to use data contained in the Economic Freedom of the World Index (2005) published by the Fraser Institute. This is a project which commenced in 1986 led by Professor Milton Friedman, Rose Friedman and Michael Walker, and is aimed at measuring the extent to which markets are operating freely, competitively and efficiently in 126 countries. This index uses quantitative/objective data as well as data from independent surveys, and indirectly attempts to assess the effects of 38 government policies on economic freedom. 
The index focuses on five major areas, with indicators relating to the size of government, legal structure and security over property rights, access to sound money, freedom to trade internationally, and regulation of credit, labour and business. For the purposes of the microeconomic efficiency component, the indicators selected is regualtion of credit, labour and business. This is chosen on the basis of their relevance to the resilience concept with regard to market efficiency.

Regulation. This component, which measures regulatory restraints that limit the freedom of exchange in credit, labour and product markets, is made up of fifteen indicators. Regulatory conditions in the domestic credit market, which are measured by assessing the extent to which the banking industry is dominated by private firms, whether foreign banks are permitted to compete in the market, the extent to which credit is supplied to the private sector and whether controls on interest rates interfere with the market in credit, measure the degree of interference by government in the financial market, which could preclude the economy from reacting flexibly to shocks.

Similar considerations apply in the case of the labour market, where unemployment benefits that undermine the incentive to accept employment, dismissal regulations, minimum wages, centralised wage setting, extensions of union contracts to nonparticipating parties and conscription, are viewed as the extent of disincentives to work in an economy, which could preclude work effort from allowing a country to recover from adverse shocks. A country would have a higher market efficiency score if it allows market forces to determine wages and establish conditions of dismissal, avoid excessive unemployment benefits that undermine work incentives, and refrain from the use of conscription.

Like the regulation of credit markets and labour markets, the regulation of business activities may inhibit market efficiency. This sub-component is designed to identify the extent to which regulatory restraints and bureaucratic procedures limit competition and the operation of markets. When regulatory activities retard entry into business and increase the cost of producing products, when prices are not market-determined and when governments use their power to extract financial payments and reward some businesses at the expense of others, they have a crowding-out effect on private sector involvement, and reduce the degree of autonomous resilience which freely-operating markets can produce.

The relative data and country ranking results are presented in Table A3.1. The data used in the index covered 2001 through to 2003. Small vulnerable countries can be found across the entire scale of placing in this index. This 
indicates that such countries are adopting different policy approaches in terms of microeconomic efficiency towards meeting adverse shocks.

Good governance. Good governance is essential for an economic system to function properly and hence, to be resilient. Governance relates to issues such as rule of law and property rights. Without mechanisms of this kind in place, it would be relatively easy for adverse shocks to result in economic and social chaos and unrest. Hence the effects of vulnerability would be magnified. On the other hand, good governance can strengthen an economy's resilience.

The Economic Freedom of the World Index (2005) has a component which is focused on legal structure and security of property rights. This is considered useful in the context of the present exercise in deriving an index of good governance. The index covers the following indicators

- judicial independence

- impartiality of courts

- the protection of intellectual property rights

- military interference in the rule of law

- political system and the integrity of the legal system.

The relative data and country ranking results for the years 2001-2003 are presented in Table A3.1. The highest rankings on the governance index are the more economically advanced countries, with the first five placings occupied by major industrialised economies. Singapore, which was among the most resilient economies on economic criteria, ranks fifteenth in terms of governance. Vulnerable economies tend to obtain lower rankings on this count, but it still appears to be the case that the vulnerable economies enjoying a higher per capita GDP also tend to have better systems of governance.

Social development. Social development is another essential component of economic resilience. This factor indicates the extent to which social relations in a society are properly developed, enabling an effective functioning of the economic apparatus without the hindrance of civil unrest. Social cohesion can also indicate the extent to which effective social dialogue takes place in an economy, which would in turn enable collaborative approaches to undertaking corrective measures in the face of adverse shocks. It is therefore hypothesised that social development is directly related to social cohesion-although this assertion cannot be tested empirically due to lack of data. 
Social development in a country can be measured in a number of ways. Variables relating to income such as its dispersion and the proportion of the population living in poverty, the long term unemployment rate, the proportion of the population with low skills and inadequate employment prospects, and the proportion of the population with low levels of education could be useful indicators. Still another possible approach would be to measure the number and extent of instances of industrial or civil unrest. These approaches are interesting but rather narrow in scope and very difficult to measure across countries.

The index presented in this paper utilises the education and health indicators used to construct the Human Development Index (UNDP 2002, 2003, 2004).

Education. Education, as measured by the adult literacy rate and school enrolment ratios, is considered to be a good indicator of social development. Education is considered to be strongly positively correlated with social advancement and hence, is indicative of a social fabric which is conducive to economic resilience.

Health. Life expectancy at birth, which is the health indicator in the Human Development Index, is considered to be suitable for measuring the health aspects in society. This in turn is likely to be related to medical facilities, housing and degree of proneness to accident or risk of injury. Again, high life expectancy is considered to be conducive to economic resilience.

The relative data and country ranking results for 2000-02 are presented in Table A3.1. The social development index is very strongly correlated with the degree of economic development, with the countries in the first 20 places on the index having an annual per capita GDP of at least US\$11,500. Small island states, including those with a high per capita GDP, rank from the twentyfifth position downwards.

Correlation between the components of the index. The variables discussed above have been found to be positively related to each other, as shown in Table 3.1 , but the correlation is somewhat weak, with the exception of good governance and market efficiency.

The question arises therefore as to whether or not the good governance index is redundant, given its high correlation with good governance. As the 
correlation is not unduly high, it was decided to retain all components in the composite index.

Other determinants of economic resilience. Economic resilience can also be viewed to be determined by a plethora of other factors apart from those mentioned above. It may be argued, for example, that it could be useful to consider the effects of environmental management on economic resilience. The environment can be an important source of vulnerability by giving rise to shocks of an adverse nature, be they rapid events, such as earthquakes, or in the form of a gradual degradation over time. In turn, these would have important repercussions on the economy and society. In this regard, the efforts being undertaken to compile the Environmental Sustainability Index (Esty et al. 2005) are commendable. Data on these factors are however not readily and extensively available across countries of different sizes, ${ }^{6}$ such that the utilisation of this index within the present exercise would have significantly reduced the countries covered by the resilience index.

In addition, there is the possibility that incorporating an environmental management index could lead to the problem of redundancy. That is, using indicators that are highly correlated which would add no new information but would render the procedure unnecessarily complex. In the case of environmental management factors, the socioeconomic resilience aspects covered by the variables discussed above are likely to be highly correlated with environmental management, although in the absence of data, this assertion cannot be tested.

\section{The resilience index}

The index was computed by taking a simple average of the four components just described, namely

- macroeconomic stability

- microeconomic market efficiency

- good governance

- social development.

\section{Table $3.1 \quad$ Correlation matrix}


All observations of the components were standardised using the well-known transformation

$$
\mathrm{XSij}=\left(\mathrm{Xij}_{\mathrm{i}}-\mathrm{Minj}\right) /(\mathrm{Maxj}-\mathrm{Minj})
$$

where $X S i j$ is the value of the standardised observation $i$ of variable $j$; $X i j$ is the actual value of the same observation; Minj and Maxj are the minimum and maximum values of variable $j$. This transforms the values of observations in a particular variable array so that they take a range of values from 0 to 1 . The results of the averaging of the four components are shown in Appendix 1. The results show that the countries with the highest GDP per capita, are, as expected, those with the highest resilience scores, as shown in Figure 3.3.

The relation between GDP per capita, resilience and vulnerability. An interesting finding is that GDP per capita of the different countries is to a very high extent explained by vulnerability and resilience. Using the OLS (ordinary least squares) method of regression, GDP per capita (standardised as explained above) was regressed on the vulnerability index (as proposed in Briguglio and Galea 2003: See Table 3A.3) and on the resilience index produced in this study. The results are shown in Table 3.2. All variables have been standardised as explained above, so that their values range between 0 and 1 .

This result confirms the hypothesis in Briguglio (2004) and Cordina (2004a, $2004 \mathrm{~b}$ ) that the performance of countries depends on their inherent vulnerability and their nurtured resilience. This is not an extraordinary finding, because it validates a very plausible assumption. However the results of the

Figure 3.3 Per capita GDP and economic resilience

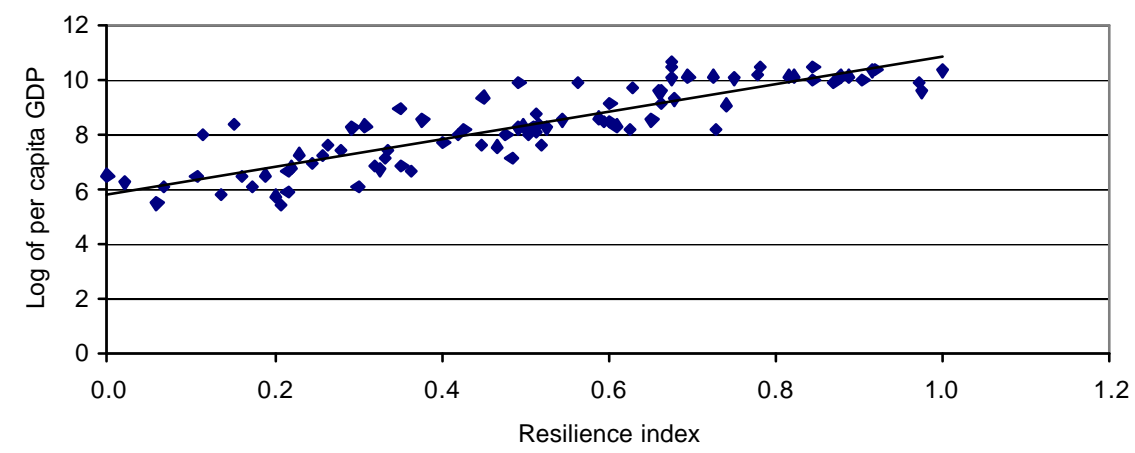


regression exercise have some interesting implications. In particular, the results show that the economic well-being of nations is more dependent on manmade policies rather than on inherent vulnerabilities. The results also confirm that adequate policy approaches can be used to overcome the handicaps posed by vulnerability.

\section{The scenarios}

Going back to the scenarios proposed in Figure 3.1, it is possible to place the countries included in the index in the four quadrants shown, using the resilience index proposed in this paper and the vulnerability index presented by Briguglio and Galea (2003). The results are shown in Figure 3.4.

It should be pointed out here that the cut-off values (represented by the dashed lines in Figure 3.4) chosen for the quadrants are the averages of the vulnerability and resilience scores for all countries. This decision is subjective and the classification of countries will change if different cut-off points are chosen. Consequently it was decided to allow a 'border-line' margin of $+/-5$ per cent for the resilience index (shown by the semi-transparent rectangle) and countries falling within this margin are classified as 'borderline' cases.

Table A3.2 shows which countries have been classified within the different quadrants.

The overall tendencies that can be derived from Table A3.2 are that

- countries which fall in the 'best-case' quadrant include the relatively large countries with a relatively high GDP per capita and relatively low vulnerability scores.

- countries which fall in the 'self-made' quadrant include a number of small states with a high vulnerability score.

- countries which fall in the 'prodigal son' quadrant include relatively large countries and others with a low resilience score.

Table 3.2 Regression results

$\begin{array}{lrrr}\mathrm{G}= & 0.14+0.94 \mathrm{R} & -0.13 \mathrm{~V} \\ \mathrm{~T} \text { stats } & (3.4) & (16.8) & -(2.6) \\ & & & \\ \mathrm{R}^{2}=0.77 & & & \\ \mathrm{~N}=87 & & & \end{array}$

Where: G=GDP per capita; R=Resilience Index; and V=Vulnerability Index 
- countries which fall in the 'worst case' quadrant include some small countries with relatively high vulnerability and low resilience scores.

\section{THE USES OF THE RESILIENCE INDEX}

\section{Supporting decision-making, setting targets and establishing standards}

Decision-making by the government and other authorities should lead to action which is systematic and coherent and based on transparent information. The Resilience Index may also be used to set the direction of action and to justify certain priorities. The index could also be useful for setting targets. For example, a country with low resilience scores in certain economic areas may set targets to step up its resilience with regard to that economic variable.

\section{Monitoring and evaluating developments}

Indices are of utmost importance to assess whether a given policy or decision is yielding the desired results and to assess whether changes of direction are needed. This is especially so if measured over time. In this way, decisions are not at risk of being taken blindly or based only on hunches and feelings, but would be based on scientific information presented in index format.

Figure 3.4 Economic resilience and economic vulnerability

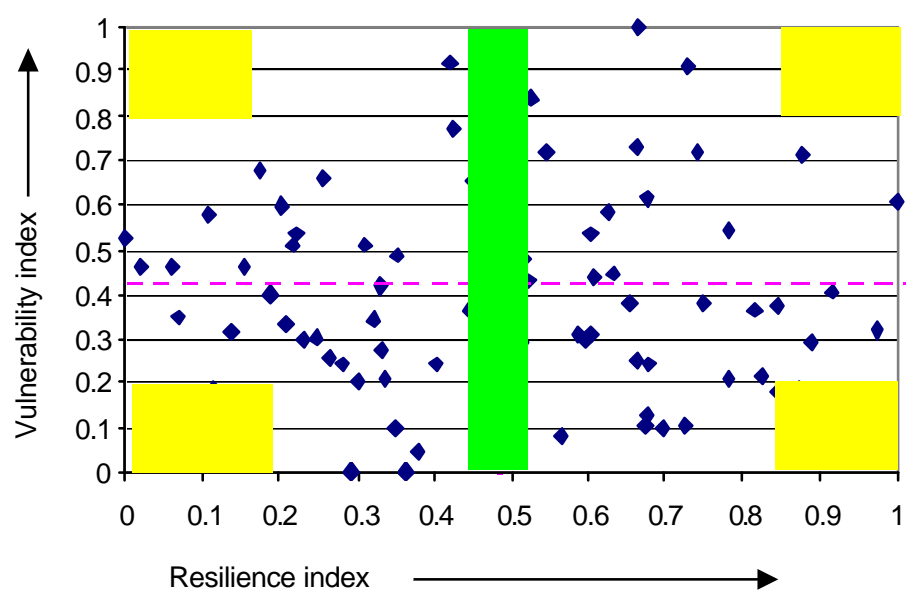




\section{Deriving quantitative estimates}

An index summarises complex phenomena, often yielding a single-value measure of the phenomena under consideration. This is useful, if not essential, for donor countries and organisations when making decisions regarding the allocation of financial and technical assistance, or for assigning special status to vulnerable countries.

\section{Dissemination of information and drawing attention to the issue}

The resilience index can be used to make the public more aware of certain problems, and to give high profiles to certain trends that can strengthen resilience. In this regard, indices can be used for communication and for alerting stakeholders about issues, including dangers, failures and success stories.

An index is a very good instrument for drawing attention to the issue being investigated. Thus, for example, the exercise of computing an index of resilience may itself make decision-makers aware of the gravity of these problems. Such an exercise may also generate academic discussion and enhance awareness amongst scholars on the issues involved.

\section{Focusing the discussion}

Indices can help to develop a common language for discussion. One often finds that persons engaged in debate go off at tangents because of lack of common definitions. In the case of indices, the quantification of its components requires precise definitions, and this could help focus the discussion on matters directly relevant to the issue.

\section{Promoting the idea of integrated action}

Composite indices are generally constructed to measure multifaceted realities. This could help to foster an awareness of the interconnections between the components of the index. In the case of economic resilience, for example, it is often not enough, and may even be counterproductive, to take action in one area in isolation from others. The resilience index proposed here could therefore promote the need for an integrated action in this regard.

\section{CONCLUSION}

This chapter dealt with conceptual and methodological aspects associated with economic resilience and its measurement. The index developed here covers four areas of economic resilience; namely, macroeconomic stability, 
microeconomic market efficiency, governance and social cohesion. Each of these areas contains variables considered suitable for gauging the extent to which the policy framework is conducive to absorbing and counteracting the effects of economic shocks.

The results of this exercise can provide an explanation as to why inherently vulnerable countries may register high levels of GNP per capita. It is argued that countries may be economically successful because they are inherently not vulnerable, or because they are resilient in the face of potential vulnerability. The obverse is also true, in that countries may be unsuccessful because they are not sufficiently resilient.

The chapter has also shown that GDP per capita is positively related to economic resilience and negatively related to inherent economic vulnerability. Furthermore, per capita GDP is found to be more sensitive to resilience than to vulnerability.

The index produced in this study is very preliminary, and the work should be considered as still at an early stage of development.

\section{NOTES}

1 In this study, the words 'state' and 'country' are used synonymously. There is no generally agreed definition as to which variable should be used to measure the size of countries and as to what should be the cut-off point between a small country and other countries. Generally speaking, population is used as an indicator of size. In this study, a country with a population of 1.5 million or less is considered to be a small one.

2 This finding is reported in many studies. See, for example, Briguglio (1995).

3 Farrugia (2004) elaborated further on these ideas by considering the economic strength of trading partners as a proxy for the probability of shocks to exports.

4 An analogy relating to an attack of influenza virus may help explain the three senses in which the term 'resilience' has been used. A person exposed to the virus may (a) get infected but recovers quickly; (b) withstand the effect of the virus, possibly by being immunised; and (c) avoid the virus altogether by staying away from infection sources.

5 It is, however, to be stated that certain countries may have external debt not because of a weak policy framework but due to a highly-developed international financial activity. This is a recognised weakness in the use of this indicator. However the inclusion of other variables related to market efficiency and governance would to an extent 'correct' this weakness, since these variables either exacerbate the effect of external debt in the presence of a weak policy framework or counteract it otherwise.

6 Esty et al. (2005) do produce some results for a few small states but they were reluctant to include them in the Environmental Sustainability Index. 
Table A3.1 Data country and ranking results

\begin{tabular}{|c|c|c|c|c|c|c|}
\hline Country & $\begin{array}{c}\text { Macroecon. } \\
\text { stability }\end{array}$ & $\begin{array}{c}\text { Microecon. } \\
\text { market } \\
\text { efficiency }\end{array}$ & $\begin{array}{c}\text { Social } \\
\text { development }\end{array}$ & $\begin{array}{c}\text { Good } \\
\text { governance }\end{array}$ & $\begin{array}{c}\text { Resilience } \\
\text { index }\end{array}$ & $\begin{array}{l}\text { Country } \\
\text { ranking }\end{array}$ \\
\hline Albania & 0.249866 & 0.386534 & 0.765396 & 0.411278 & 0.453268 & 63 \\
\hline Argentina & 0.533841 & 0.258845 & 0.868035 & 0.226565 & 0.471822 & 59 \\
\hline Australia & 0.471526 & 0.80043 & 0.98827 & 0.970713 & 0.807735 & 9 \\
\hline Austria & 0.692709 & 0.531446 & 0.956012 & 0.927846 & 0.777003 & 12 \\
\hline Bangladesh & 0.635215 & 0.304511 & 0.222874 & 0.17407 & 0.334168 & 81 \\
\hline Barbados & 0.631647 & 0.626714 & 0.914956 & 0.721573 & 0.723723 & 17 \\
\hline Belgium & 0.661383 & 0.474074 & 0.982405 & 0.799757 & 0.729405 & 16 \\
\hline Belize & 0.186241 & 0.670694 & 0.753666 & 0.607275 & 0.554469 & 49 \\
\hline Bolivia & 0.46827 & 0.360133 & 0.618768 & 0.173626 & 0.405199 & 70 \\
\hline Brazil & 0.388055 & 0.209704 & 0.721408 & 0.423359 & 0.435631 & 66 \\
\hline Cameroon & 0.443272 & 0.451458 & 0.231672 & 0.343852 & 0.367563 & 77 \\
\hline Canada & 0.632888 & 0.797511 & 0.97654 & 0.910253 & 0.829298 & 6 \\
\hline Chile & 0.635734 & 0.561847 & 0.859238 & 0.610715 & 0.666883 & 28 \\
\hline China & 0.653449 & 0.094953 & 0.703812 & 0.468426 & 0.48016 & 57 \\
\hline Colombia & 0.417252 & 0.272723 & 0.753666 & 0.219628 & 0.415817 & 68 \\
\hline Costa Rica & 0.608614 & 0.469847 & 0.853372 & 0.623045 & 0.63872 & 31 \\
\hline Cote d'Ivoire & 0.421575 & 0.327188 & 0 & 0.236807 & 0.246392 & 87 \\
\hline Croatia & 0.524189 & 0.516349 & 0.824047 & 0.450516 & 0.578775 & 40 \\
\hline Cyprus & 0.360269 & 0.406994 & 0.88563 & 0.687058 & 0.584988 & 38 \\
\hline Czech Republic & 0.570785 & 0.444326 & 0.856305 & 0.630779 & 0.625549 & 35 \\
\hline Denmark & 0.716137 & 0.682179 & 0.944282 & 1 & 0.83565 & 5 \\
\hline Dominican Republic & 0.656766 & 0.469506 & 0.653959 & 0.304935 & 0.521291 & 53 \\
\hline Egypt, Arab Rep. & 0.587887 & 0.150975 & 0.504399 & 0.403256 & 0.411629 & 69 \\
\hline El Salvador & 0.655256 & 0.484604 & 0.645161 & 0.351327 & 0.534087 & 52 \\
\hline Estonia & 0.634994 & 0.705067 & 0.85044 & 0.673152 & 0.715913 & 18 \\
\hline Finland & 0.638404 & 0.670794 & 0.970674 & 0.996864 & 0.819184 & 7 \\
\hline France & 0.49435 & 0.525839 & 0.961877 & 0.743736 & 0.68145 & 23 \\
\hline Germany & 0.550882 & 0.348942 & 0.947214 & 0.931598 & 0.694659 & 20 \\
\hline Greece & 0.376219 & 0.289183 & 0.929619 & 0.550436 & 0.536364 & 51 \\
\hline Honduras & 0.425194 & 0.38848 & 0.583578 & 0.1569 & 0.388538 & 72 \\
\hline Hong Kong, China & 0.649945 & 1 & 0.865103 & 0.730719 & 0.811442 & 8 \\
\hline Hungary & 0.435458 & 0.598013 & 0.829912 & 0.656447 & 0.629957 & 34 \\
\hline Iceland & 0.722204 & 0.911862 & 0.967742 & 0.960131 & 0.890485 & 1 \\
\hline India & 0.501144 & 0.309005 & 0.395894 & 0.555138 & 0.440295 & 65 \\
\hline Indonesia & 0.419976 & 0.06043 & 0.633431 & 0.285343 & 0.349795 & 79 \\
\hline Iran, Islamic Rep. & 0.594709 & 0 & 0.630499 & 0.555373 & 0.445145 & 64 \\
\hline Ireland & 0.748274 & 0.631891 & 0.926686 & 0.854979 & 0.790458 & 11 \\
\hline Israel & 0.598613 & 0.348255 & 0.932551 & 0.729831 & 0.652313 & 29 \\
\hline Italy & 0.563878 & 0.27718 & 0.929619 & 0.668735 & 0.609853 & 36 \\
\hline Jamaica & 0.403985 & 0.412831 & 0.782991 & 0.467962 & 0.516942 & 54 \\
\hline Japan & 0.473191 & 0.530351 & 0.973607 & 0.74548 & 0.680657 & 24 \\
\hline Jordan & 0.388433 & 0.480286 & 0.727273 & 0.637369 & 0.55834 & 48 \\
\hline Kenya & 0.48918 & 0.470737 & 0.29912 & 0.282871 & 0.385477 & 74 \\
\hline
\end{tabular}




\begin{tabular}{|c|c|c|c|c|c|c|}
\hline Country & stability & efficiency & development & governance & index & ranking \\
\hline Kuwait & 0.578993 & 0.655568 & 0.747801 & 0.705003 & 0.671841 & 27 \\
\hline Latvia & 0.522574 & 0.489853 & 0.824047 & 0.554741 & 0.597804 & 37 \\
\hline Lithuania & 0.548288 & 0.39104 & 0.847507 & 0.470706 & 0.564385 & 46 \\
\hline Luxembourg & 0.169854 & 0.751959 & 0.894428 & 0.910095 & 0.681584 & 22 \\
\hline Madagascar & 0.362156 & 0.266086 & 0.255132 & 0.25639 & 0.284941 & 85 \\
\hline Malaysia & 0.731697 & 0.493283 & 0.747801 & 0.624907 & 0.649422 & 30 \\
\hline Malta & 0.484228 & 0.631271 & 0.870968 & 0.70835 & 0.673704 & 25 \\
\hline Mauritius & 0.601564 & 0.370945 & 0.70088 & 0.624736 & 0.574531 & 43 \\
\hline Mexico & 0.606521 & 0.281145 & 0.777126 & 0.294478 & 0.489818 & 56 \\
\hline Morocco & 0.495981 & 0.372758 & 0.404692 & 0.566488 & 0.45998 & 61 \\
\hline Nepal & 0.4917 & 0.457864 & 0.260997 & 0.309663 & 0.380056 & 75 \\
\hline Netherlands & 0.482792 & 0.65624 & 0.979472 & 0.971333 & 0.772459 & 13 \\
\hline New Zealand & 0.690428 & 0.882142 & 0.973607 & 0.950714 & 0.874223 & 2 \\
\hline Nicaragua & 0.023774 & 0.48574 & 0.565982 & 0.18658 & 0.315519 & 83 \\
\hline Nigeria & 0.471854 & 0.508743 & 0.231672 & 0.219478 & 0.357937 & 78 \\
\hline Norway & 0.556971 & 0.549727 & 0.982405 & 0.909665 & 0.749692 & 14 \\
\hline Pakistan & 0.394713 & 0.414384 & 0.205279 & 0.148316 & 0.290673 & 84 \\
\hline Panama & 0.582466 & 0.536143 & 0.806452 & 0.384237 & 0.577324 & 42 \\
\hline Papua New Guinea & 0.508531 & 0.433815 & 0.290323 & 0.310375 & 0.385761 & 73 \\
\hline Paraguay & 0.578202 & 0.164149 & 0.730205 & 0.105776 & 0.394583 & 71 \\
\hline Peru & 0.568293 & 0.401304 & 0.739003 & 0.315774 & 0.506094 & 55 \\
\hline Philippines & 0.451332 & 0.387922 & 0.771261 & 0.284718 & 0.473808 & 58 \\
\hline Poland & 0.56857 & 0.304017 & 0.8739 & 0.520459 & 0.566737 & 45 \\
\hline Portugal & 0.59533 & 0.458159 & 0.914956 & 0.768367 & 0.684203 & 21 \\
\hline Romania & 0.38811 & 0.290391 & 0.765396 & 0.408514 & 0.463103 & 60 \\
\hline Russian Federation & 0.517208 & 0.092389 & 0.750733 & 0.348189 & 0.42713 & 67 \\
\hline Senegal & 0.403354 & 0.225306 & 0.067449 & 0.342088 & 0.259549 & 86 \\
\hline Singapore & 1 & 0.729691 & 0.876833 & 0.887539 & 0.873516 & 3 \\
\hline Slovak Republic & 0.446169 & 0.445685 & 0.829912 & 0.535593 & 0.56434 & 47 \\
\hline Slovenia & 0.660042 & 0.307871 & 0.903226 & 0.664043 & 0.633796 & 33 \\
\hline South Africa & 0.576064 & 0.600028 & 0.445748 & 0.663719 & 0.57139 & 44 \\
\hline Spain & 0.54459 & 0.556156 & 0.967742 & 0.624577 & 0.673266 & 26 \\
\hline Sri Lanka & 0.318068 & 0.406613 & 0.750733 & 0.355834 & 0.457812 & 62 \\
\hline Sweden & 0.473626 & 0.573594 & 1 & 0.948877 & 0.749024 & 15 \\
\hline Switzerland & 0.556796 & 0.74385 & 0.950147 & 0.912063 & 0.790714 & 10 \\
\hline Thailand & 0.398987 & 0.473332 & 0.733138 & 0.582446 & 0.546975 & 50 \\
\hline Trinidad and Tobago & 0.640791 & 0.561979 & 0.780059 & 0.557279 & 0.635027 & 32 \\
\hline Tunisia & 0.510781 & 0.484403 & 0.651026 & 0.682657 & 0.582217 & 39 \\
\hline Turkey & 0 & 0.212651 & 0.674487 & 0.391459 & 0.319649 & 82 \\
\hline Uganda & 0.515504 & 0.424067 & 0.199413 & 0.369793 & 0.377194 & 76 \\
\hline United Kingdom & 0.062219 & 0.844121 & 0.970674 & 0.977112 & 0.713532 & 19 \\
\hline United States & 0.646397 & 0.906787 & 0.944282 & 0.859822 & 0.839322 & 4 \\
\hline Uruguay & 0.523452 & 0.375556 & 0.8739 & 0.537029 & 0.577484 & 41 \\
\hline Venezuela, RB & 0.511099 & 0.09085 & 0.777126 & 0 & 0.344769 & 80 \\
\hline
\end{tabular}




\section{Table A3.2 The four scenarios}

\begin{tabular}{|c|c|c|c|c|}
\hline Country & Resilience Index & Vulnerability Index & Case & Borderline \\
\hline Barbados & 0.741 & 0.717 & Self Made & \\
\hline Costa Rica & 0.609 & 0.436 & Self Made & \\
\hline Cyprus & 0.526 & 0.840 & Self Made & \\
\hline Estonia & 0.729 & 0.908 & Self Made & \\
\hline Hong Kong, China & 0.877 & 0.713 & Self Made & \\
\hline Iceland & 1.000 & 0.607 & Self Made & \\
\hline Israel & 0.630 & 0.443 & Self Made & \\
\hline Kuwait & 0.661 & 0.731 & Self Made & \\
\hline Latvia & 0.546 & 0.718 & Self Made & \\
\hline Luxembourg & 0.676 & 0.615 & Self Made & \\
\hline Malaysia & 0.626 & 0.587 & Self Made & \\
\hline Malta & 0.663 & 1.000 & Self Made & \\
\hline Norway & 0.781 & 0.543 & Self Made & \\
\hline Singapore & 0.974 & 0.971 & Self Made & \\
\hline Trinidad and Tobago & 0.603 & 0.533 & Self Made & \\
\hline Croatia & 0.516 & 0.480 & Self Made & Borderline \\
\hline Mauritius & 0.509 & 0.632 & Self Made & Borderline \\
\hline Panama & 0.514 & 0.837 & Self Made & Borderline \\
\hline Tunisia & 0.521 & 0.426 & Self Made & Borderline \\
\hline Australia & 0.872 & 0.184 & Best Case & \\
\hline Austria & 0.824 & 0.216 & Best Case & \\
\hline Belgium & 0.750 & 0.384 & Best Case & \\
\hline Canada & 0.905 & 0.117 & Best Case & \\
\hline Chile & 0.653 & 0.379 & Best Case & \\
\hline Czech Republic & 0.589 & 0.309 & Best Case & \\
\hline Denmark & 0.915 & 0.407 & Best Case & \\
\hline Finland & 0.889 & 0.286 & Best Case & \\
\hline France & 0.675 & 0.129 & Best Case & \\
\hline Germany & 0.696 & 0.100 & Best Case & \\
\hline Hungary & 0.596 & 0.294 & Best Case & \\
\hline Ireland & 0.845 & 0.371 & Best Case & \\
\hline Italy & 0.564 & 0.082 & Best Case & \\
\hline Japan & 0.674 & 0.106 & Best Case & \\
\hline Netherlands & 0.817 & 0.364 & Best Case & \\
\hline New Zealand & 0.975 & 0.320 & Best Case & \\
\hline Portugal & 0.680 & 0.242 & Best Case & \\
\hline Slovenia & 0.601 & 0.307 & Best Case & \\
\hline Spain & 0.663 & 0.250 & Best Case & \\
\hline Sweden & 0.780 & 0.208 & Best Case & \\
\hline Switzerland & 0.845 & 0.178 & Best Case & \\
\hline United Kingdom & 0.725 & 0.106 & Best Case & \\
\hline United States & 0.921 & 0.060 & Best Case & \\
\hline South Africa & 0.505 & 0.147 & Best Case & Borderline \\
\hline
\end{tabular}




\begin{tabular}{|c|c|c|c|c|}
\hline Country & Resilience Index & Vulnerability Index & Case & Borderline \\
\hline Uruguay & 0.514 & 0.288 & Best Case & Borderline \\
\hline Cote d'Ivoire & 0.000 & 0.524 & Worst Case & \\
\hline Dominican Republic & 0.427 & 0.768 & Worst Case & \\
\hline Egypt, Arab Rep. & 0.257 & 0.658 & Worst Case & \\
\hline Greece & 0.450 & 0.655 & Worst Case & \\
\hline Honduras & 0.221 & 0.534 & Worst Case & \\
\hline Iran, Islamic Rep. & 0.309 & 0.508 & Worst Case & \\
\hline Jamaica & 0.420 & 0.922 & Worst Case & \\
\hline Kenya & 0.216 & 0.511 & Worst Case & \\
\hline Madagascar & 0.060 & 0.465 & Worst Case & \\
\hline Nicaragua & 0.107 & 0.578 & Worst Case & \\
\hline Nigeria & 0.173 & 0.677 & Worst Case & \\
\hline Papua New Guinea & 0.216 & 0.508 & Worst Case & \\
\hline Philippines & 0.353 & 0.485 & Worst Case & \\
\hline Senegal & 0.020 & 0.464 & Worst Case & \\
\hline Sri Lanka & 0.328 & 0.415 & Worst Case & \\
\hline Uganda & 0.203 & 0.597 & Worst Case & \\
\hline Belize & 0.478 & 0.768 & Worst Case & Borderline \\
\hline Jordan & 0.484 & 0.725 & Worst Case & Borderline \\
\hline Lithuania & 0.494 & 0.466 & Worst Case & Borderline \\
\hline Albania & 0.321 & 0.344 & Prodigal Son & \\
\hline Argentina & 0.350 & 0.100 & Prodigal Son & \\
\hline Bangladesh & 0.136 & 0.313 & Prodigal Son & \\
\hline Bolivia & 0.247 & 0.299 & Prodigal Son & \\
\hline Brazil & 0.294 & 0.001 & Prodigal Son & \\
\hline Cameroon & 0.188 & 0.397 & Prodigal Son & \\
\hline China & 0.363 & 0.000 & Prodigal Son & \\
\hline Colombia & 0.263 & 0.254 & Prodigal Son & \\
\hline El Salvador & 0.447 & 0.362 & Prodigal Son & \\
\hline India & 0.301 & 0.201 & Prodigal Son & \\
\hline Indonesia & 0.161 & 0.174 & Prodigal Son & \\
\hline Mexico & 0.378 & 0.046 & Prodigal Son & \\
\hline Morocco & 0.332 & 0.272 & Prodigal Son & \\
\hline Nepal & 0.208 & 0.327 & Prodigal Son & \\
\hline Pakistan & 0.069 & 0.349 & Prodigal Son & \\
\hline Paraguay & 0.230 & 0.297 & Prodigal Son & \\
\hline Peru & 0.403 & 0.242 & Prodigal Son & \\
\hline Romania & 0.336 & 0.206 & Prodigal Son & \\
\hline Russian Federation & 0.281 & 0.241 & Prodigal Son & \\
\hline Thailand & 0.467 & 0.363 & Prodigal Son & \\
\hline Turkey & 0.114 & 0.182 & Prodigal Son & \\
\hline Venezuela, RB & 0.153 & 0.465 & Prodigal Son & \\
\hline Poland & 0.497 & 0.175 & Prodigal Son & Borderline \\
\hline Slovak Republic & 0.494 & 0.357 & Prodigal Son & Borderline \\
\hline
\end{tabular}




\section{Pacific Island Regional Integration and Governance}

Table A3.3 The Briguglio and Galea vulnerability index

\begin{tabular}{|c|c|c|}
\hline Country & Vulnerability Index & Country Ranking \\
\hline Albania & 0.263 & 50 \\
\hline Argentina & 0.077 & 81 \\
\hline Australia & 0.141 & 71 \\
\hline Austria & 0.166 & 67 \\
\hline Bangladesh & 0.240 & 53 \\
\hline Barbados & 0.549 & 12 \\
\hline Belgium & 0.294 & 42 \\
\hline Belize & 0.588 & 7 \\
\hline Bolivia & 0.229 & 56 \\
\hline Brazil & 0.001 & 86 \\
\hline Cameroon & 0.304 & 41 \\
\hline Canada & 0.089 & 78 \\
\hline Chile & 0.290 & 43 \\
\hline China & 0.000 & 87 \\
\hline Colombia & 0.194 & 62 \\
\hline Costa Rica & 0.334 & 37 \\
\hline Cote d'Ivoire & 0.401 & 26 \\
\hline Croatia & 0.368 & 31 \\
\hline Cyprus & 0.643 & 5 \\
\hline Czech Republic & 0.236 & 54 \\
\hline Denmark & 0.311 & 40 \\
\hline Dominican Republic & 0.588 & 8 \\
\hline Egypt, Arab Rep. & 0.504 & 15 \\
\hline El Salvador & 0.277 & 47 \\
\hline Estonia & 0.695 & 4 \\
\hline Finland & 0.219 & 60 \\
\hline France & 0.099 & 77 \\
\hline Germany & 0.076 & 82 \\
\hline Greece & 0.501 & 16 \\
\hline Honduras & 0.409 & 24 \\
\hline Hong Kong, China & 0.546 & 13 \\
\hline Hungary & 0.225 & 58 \\
\hline Iceland & 0.465 & 19 \\
\hline India & 0.154 & 70 \\
\hline Indonesia & 0.133 & 75 \\
\hline Iran, Islamic Rep. & 0.389 & 28 \\
\hline Ireland & 0.284 & 44 \\
\hline Israel & 0.339 & 36 \\
\hline Italy & 0.062 & 83 \\
\hline Jamaica & 0.706 & 3 \\
\hline Japan & 0.081 & 79 \\
\hline Jordan & 0.555 & 10 \\
\hline Kenya & 0.391 & 27 \\
\hline Kuwait & 0.560 & 9 \\
\hline Latvia & 0.550 & 11 \\
\hline Lithuania & 0.357 & 32 \\
\hline Luxembourg & 0.471 & 18 \\
\hline Madagascar & 0.356 & 34 \\
\hline Malaysia & 0.449 & 21 \\
\hline Malta & 0.765 & 1 \\
\hline
\end{tabular}




\section{Table A3.3 The Briguglio and Galea vulnerability index}

\begin{tabular}{|c|c|c|}
\hline Country & Vulnerability Index & Country ranking \\
\hline Mauritius & 0.484 & 17 \\
\hline Mexico & 0.035 & 85 \\
\hline Morocco & 0.208 & 61 \\
\hline Nepal & 0.250 & 51 \\
\hline Netherlands & 0.279 & 45 \\
\hline New Zealand & 0.245 & 52 \\
\hline Nicaragua & 0.442 & 22 \\
\hline Nigeria & 0.518 & 14 \\
\hline Norway & 0.416 & 23 \\
\hline Pakistan & 0.267 & 49 \\
\hline Panama & 0.640 & 6 \\
\hline Papua New Guinea & 0.389 & 29 \\
\hline Paraguay & 0.227 & 57 \\
\hline Peru & 0.186 & 64 \\
\hline Philippines & 0.371 & 30 \\
\hline Poland & 0.134 & 74 \\
\hline Portugal & 0.185 & 65 \\
\hline Romania & 0.158 & 69 \\
\hline Russian Federation & 0.184 & 66 \\
\hline Senegal & 0.355 & 35 \\
\hline Singapore & 0.743 & 2 \\
\hline Slovak Republic & 0.273 & 48 \\
\hline Slovenia & 0.235 & 55 \\
\hline South Africa & 0.113 & 76 \\
\hline Spain & 0.192 & 63 \\
\hline Sri Lanka & 0.318 & 39 \\
\hline Sweden & 0.159 & 68 \\
\hline Switzerland & 0.136 & 73 \\
\hline Thailand & 0.278 & 46 \\
\hline Trinidad and Tobago & 0.408 & 25 \\
\hline Tunisia & 0.326 & 38 \\
\hline Turkey & 0.140 & 72 \\
\hline Uganda & 0.457 & 20 \\
\hline United Kingdom & 0.081 & 80 \\
\hline United States & 0.046 & 84 \\
\hline Uruguay & 0.221 & 59 \\
\hline Venezuela, RB & 0.356 & 33 \\
\hline
\end{tabular}

Source: Briguglio, L. and Galea, W., 2003. Updating the Economic Vulnerability Index, Occasional Papers on Islands and Small States 2003-4, Islands and Small States Institute, Malta. 